\title{
Paleohydrological Reconstruction from Late Holocene Records in Interdune Lakes (N'Guigmi, Northern Bank of the Lake Chad, Niger)
}

\author{
David Sebag $^{1,2}$, Alain Durand ${ }^{1}$, Zibo Garba ${ }^{3}$, Eric P. Verrecchia ${ }^{4}$ \\ ${ }^{1}$ Laboratoire Morphodynamique Continentale et Côtière, Université de Rouen, \\ Centre National de la Recherche Scientifique (CNRS), Rouen, France \\ ${ }^{2}$ Laboratoire HydroSciences Montpellier, Institut de Recherche pour le Développement (IRD), \\ Université de Ngaoundéré, Cameroun, France \\ ${ }^{3}$ Département de Géologie, Université Abdou Moumouni, Niamey, Niger \\ ${ }^{4}$ Institut des Sciences de la Terre, Université de Lausanne, Lausanne, Switzerland \\ Email: david.sebag@univ-rouen.fr
}

Received February 3, 2013; revised March 8, 2013; accepted April 8, 2013

Copyright (C) 2013 David Sebag et al. This is an open access article distributed under the Creative Commons Attribution License, which permits unrestricted use, distribution, and reproduction in any medium, provided the original work is properly cited.

\begin{abstract}
An old erg covers the northern part of the Lake Chad basin. This dune landform allowed the formation of many interdune ponds of various sizes. Still present in certain zones where the groundwater level is high (e.g. Kanem, southern Manga), these ponds formed in the past a vast network of lacustrine microsystems, as shown by the nature and the distribution of their deposits. In the Manga, these interdune deposits represent the main sedimentary records of the Holocene environmental succession. Their paleobiological (pollens, diatoms, ostracods) and geochemical $(\delta 18 \mathrm{O}, \delta 13 \mathrm{C}, \mathrm{Sr} /$ $\mathrm{Ca})$ contents are often the basis for paleoenvironmental reconstruction. On the other hand, their sedimentological characters are rarely exploited. This study of palustro-lacustrine deposits of the Holocene N'Guigmi lake (northern bank of the Lake Chad; Niger) is based on the relationships between the sedimentological features and the climato-hydrological fluctuations. The mineralogical parameters (e.g. calcium carbonate content, clay mineralogy) and the nature of autochthonous mineralization (i.e. amorphous silica, clays, calcium carbonates) can be interpreted using a straightforward hydro-sedimentary model. Established to explain the geochemical dynamics of Lake Chad, this model is based on a biogeochemical cycle of the main elements (i.e. silicium, calcium) directly controlled by the local hydrological balance (i.e. rainfall/evaporation ratio). All these results show that a detailed study of sedimentological features can provide important paleohydrological informations about the regional aridification since ca $650014 \mathrm{C} \mathrm{BP}$.
\end{abstract}

Keywords: Sahel; Lake Chad; Holocene; Mineralogy; Depositional Environments; Climate Change

\section{Introduction}

The first geological in-deph information of Eastern Niger (about $500,000 \mathrm{~km}^{2}$ ) is given in Hugues Faure's thesis [1]. Relating to the post-Paleozoic sedimentary formations, this study also included innovative observations about the Quaternary period. Faure [1] was the first to show the stratigraphical relationship between the Quaternary deposits, the substratum and the Plio-Villafranchian on a geological log. He was also the first to consider erosional processes and tectonics of interest. In particular, he was one of the first to use radiocarbon dating in Africa. He contributed to the establishment of the true chronology of the dramatic Upper Quaternary climatic changes. These changes have been recognized for a long time, but the presumed ages varied from Tertiary to the last century [2]. He was also the first to combine radiocarbon dating with environmental biomarkers (i.e. diatoms; [3]) in these areas where interdune lacustrine deposits are numerous.

Applied to isolated samples, this approach has considerably improved the study of geological sections, thus making possible the palaeo-environmental reconstruction of Upper Pleistocene and Holocene history with an increasingly higher-resolution $[4,5]$. Nowadays, several biomarkers are used, such as pollens, ostracods, phytoliths [6-10], and geochemical markers are also used to study authigenous or biogenic carbonates, such as $\delta 18 \mathrm{O}, \delta 13 \mathrm{C}$, $\mathrm{Mg} / \mathrm{Ca}, \mathrm{Sr} / \mathrm{Ca}$ [8-12]. However, in these studies, the sedimentological analyses of the deposits are lacking or 
quite basic $[13,14]$. A few studies only used sedimentological analyses because the sediments are detrital and azoic [15-17], or chemical in origin [18]. In interdune environments, the groundwater level is often close to the surface; the same sedimentary deposits can thus record several hydro-climatic events. In this case, only a sedimentological analysis allows better understanding the processes of reworking, gaps, and diagenesis. Therefore, it is critical to understand the origin of sediments and sedimentary dynamics, and particularly the origin of carbonates providing the radiocarbon dates $[13,15,19,20]$.

In this geographic area, previous studies about present-day hydro-sedimentary mechanisms make this approach easier. In fact, an "Opération Concertée Multidisciplinaire" in the Lake Chad basin was carried out by the IRD from 1965 on the Hugues Faure's initiative. The objectives of this project were to establish how the present-day environment works and its dynamics on the annual or ten-year scale. This allowed a better understanding of equivalent Upper Quaternary geosystems [21].

In this paper, a similar approach is used to understand the dynamics of N'Guigmi Holocene interdune lake, where diatoms and carbonate isotopes have already been studied $[5,12,22]$.

\section{Geological Setting}

The studied area is located in the southern Manga. The Manga is an ancient erg underlain by Terminal Continental Sandstones. The erg's slope measures $120 \mathrm{~km}$ and rises between 400 and $285 \mathrm{~m}$ asl from NW to SE. This low declivity and the permeability of the sandy watershed prevent the formation of a significant hydrographic network. The dunes consist of slighty weathered, reddened, well-sorted fine to medium sands. They form a rolling upland mostly covered by annual grasses and shrubs with scattered trees, such as Acacia albida, Balanites aegyptiaca, and Adansonia digitata [14]. Shallow, mainly seasonal, playa lakes supporting dense blooms of cyanobacteria and diatoms occupy the deeper interdune depressions.

The water-level fluctuations are directly related to the sparse rainfall in the Sahel zone. The dune sands are highly permeable, resulting in a rapid response $(5-10 \mathrm{yr})$ of groundwater outflow to interannual variations in summer rainfall [14]. The shallow aquifer is independent of Lake Chad, being actively recharged by local precipitation generated mainly (about 75\%) by westward-propagating squall lines during the summer-monsoon season (June-September) when the Intertropical Convergence Zone reaches its most northerly position.

At N'Guigmi, annual rainfall averaged ca. $260 \mathrm{~mm}$ between 1950 and 1969 and ca.175 mm between 1971 and 1991 [23]. With an annual average temperature of $28^{\circ} \mathrm{C}$ and a potential evapotranspiration of $2300 \mathrm{~mm}$ [24], this region marks the limit between semi-arid and arid zones.

In the studied area, Durand et al. [22] distinguished three geomorphologic domains (Figure 1): a northern wind-dominated domain (sandy plateau of southern Manga), a southwestern fluvial domain (Kadzell or alluvial plain of the Yobe River) and a southeastern lacustrine domain (Lake Chad). The wind-dominated domain corresponds to an old erg strongly reactivated during the Kanemian period ( $>15,000$ years $14 \mathrm{C} \mathrm{BP})$, then partly
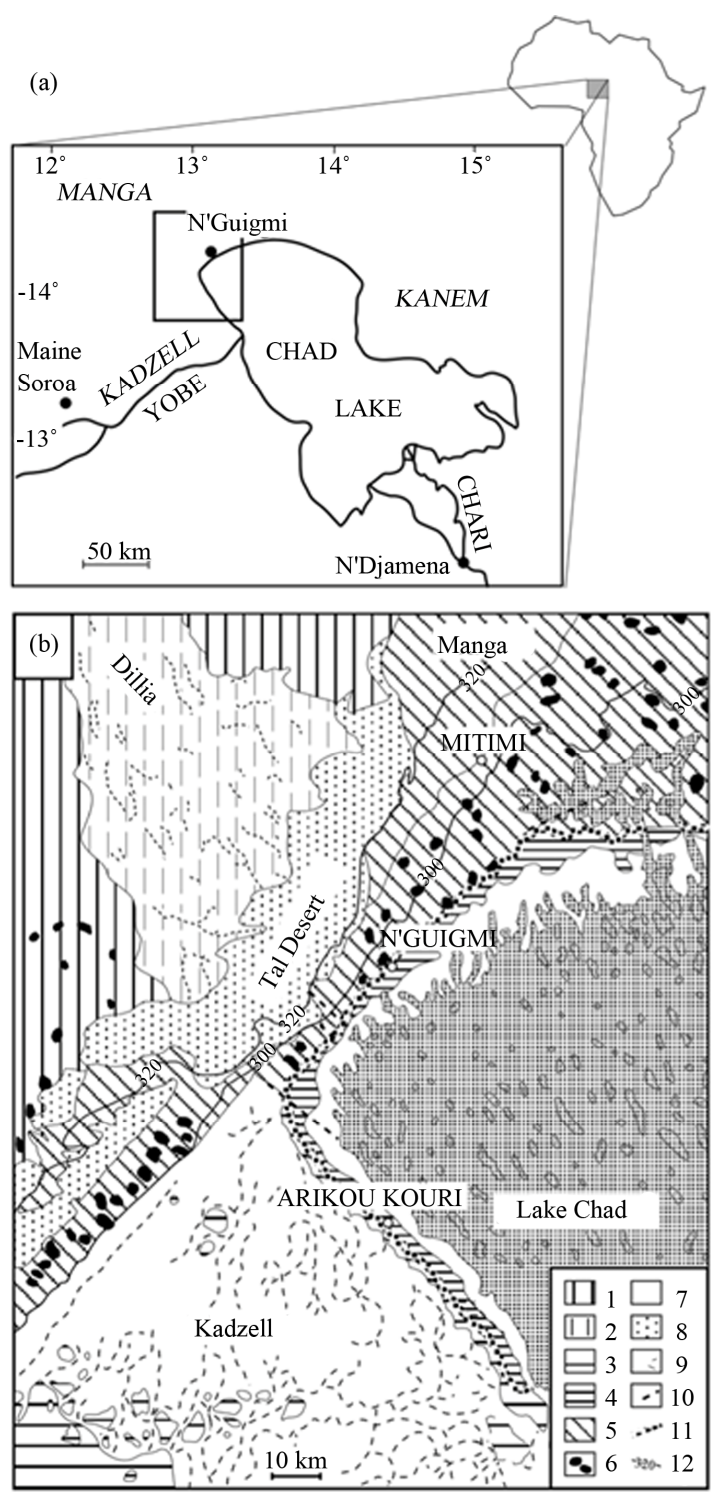

Figure 1. (a) Localisation of sites on the scale of Africa and Lake Chad; (b) Geomorphological setting of studied area (Durand et al., 1984; Durand, 1997). 1) Manga Plateau: old erg wind-levelled; 2) Grande Dillia: fault trough; 3) Yobe River's old terraces; 4) Tardiglacial and Holocene beaches and deposits; 5) Manga Plateau's slope levelled by the wind an run-off towards the southwest, and by lacustrine transgressions in the area bordering the Lake Chad. 
leveled by the wind and the local runoff resulting from rainfall.

During the Kanemian, the wind-dominated domain extended towards the south [2], which today constitutes the floor of the present Lake Chad. Conversely, the lacustrine banks moved towards the north during the wetter periods (Holocene lacustrine beaches; Figure 1). However, recent aeolian dynamics can be locally significant with deflation (Mitimi plateau) or deposition (Tal desert or recent peri-lacustrine dune ridge; Figure 1).

\section{Material Studied}

$\mathrm{N}^{\prime}$ Guigmi city $\left(14^{\circ} 15^{\prime} \mathrm{N}, 13^{\circ} 07^{\prime} \mathrm{E}\right)$ is built on an ancient lacustrine beach, on the northwestern bank of Lake Chad. It leans against the recent peri-lacustrine dune ridge, which separates the aeolian and lacustrine environments (Figure 1(b)).

The studied sections have been sampled in a depression located behind the peri-lacustrine dune ridge, to the northwest of the city (Figure 2(a)). Clayey calcareous deposits fill this depression. The trigonometric leveling performed during the sampling allows the measurement of the depression infilling within ten centimeters (Figure 2(b)).

The oldest clayey calcareous deposits are limited to the central and deepest part of the depression (Figure 2(b)). Because of the paleotopography, the sandy depression is interpreted as one of the interdune depressions in the sandy plateau of southern Manga (Figure 1(b)).

Its southern side has been strongly wind-reworked. The sand of the recent peri-lacustrine dune ridge presently accumulates on the clayey calcareous deposits (Figure 2(b)) reaching ca 296 - $298 \mathrm{~m}$. On the northern side of the interdune depression, the recent sand accumulation only leads to the formation of small dunes (Figure 2(b)).

The main section (NGI-1) is located at the centre of the depression (Figure 2(b)). The sediments of the 250 cm thick section are composed of: 1) sandy deposits, 2) clayey deposits and clayey calcareous diatomite, and 3) modern wind-reworked sandy material (Figure 3). The sampling was made every $5 \mathrm{~cm}$, from the base to the top, respecting the apparent lithological limits. At the bottom, the groundwater level limited the sampling.

Located 209 meters to the north of the main section, the NGI-10 section is $175 \mathrm{~cm}$ thick. It comprises clayey silty diatomite with various amounts of carbonates, organic matter (OM), and woody and coal fragments. Only ten samples were taken on lithological criteria. This section differs mainly from the others by the presence of numerous siliceous concretions. This indicates particular hydrological and diagenetic conditions in this part of the depression, which are related to a shallow place or blind embayment on the northern bank [25].

\section{Methods}

Several samples show a heterogeneous distribution of
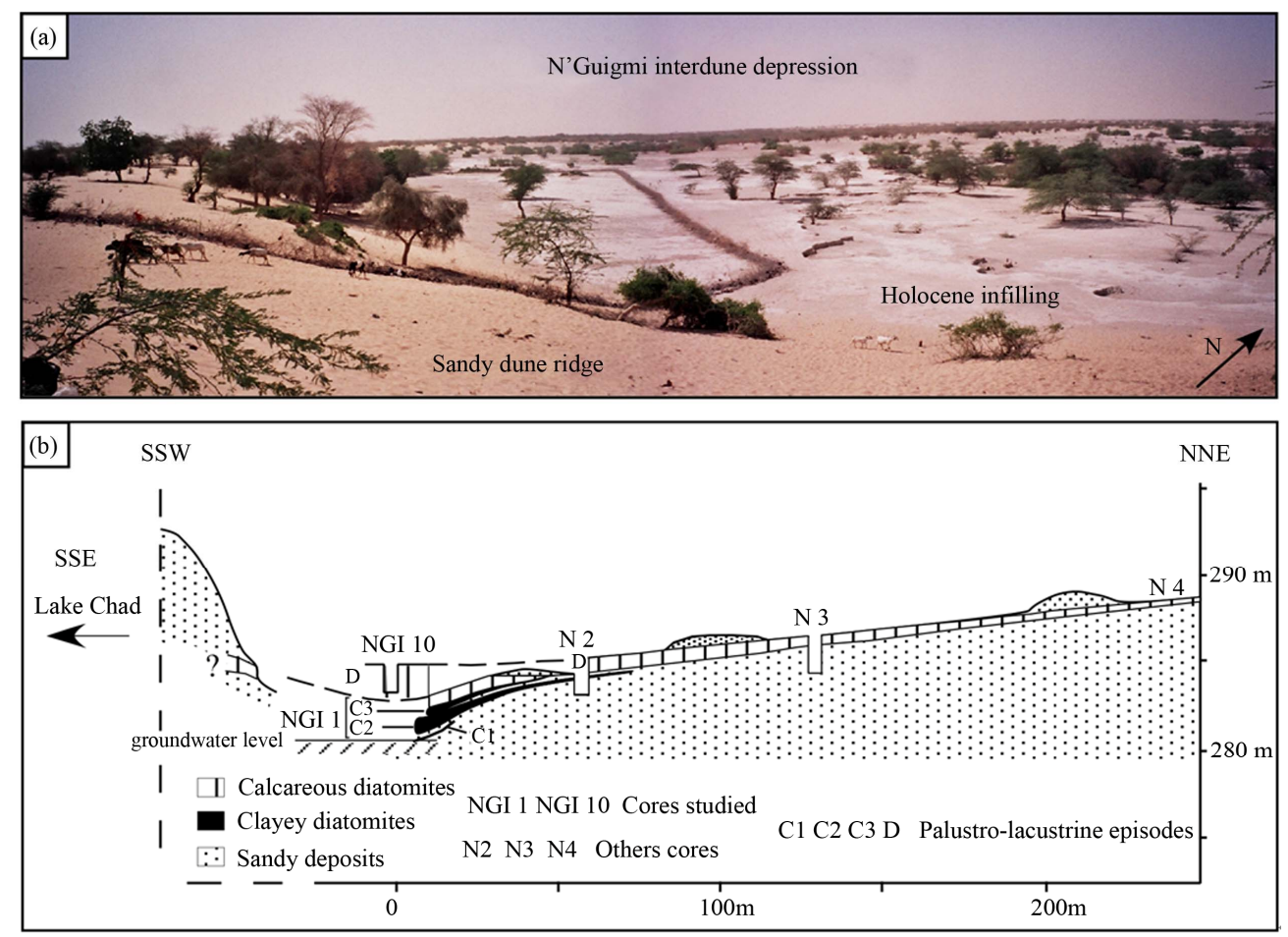

Figure 2. (a) N'Guigmi depression (Dec. 2002); (b) Location, levelling and correlations of N'Guigmi section (Durand, 1995). 
their constituents (i.e. woody remains, calcareous and siliceous concretions, mollusk shells). Each sample was homogenized to avoid any representativeness problems. Thus, the results from the various analytical methods can be compared with an average value for a single sample.

The calcium carbonate content has been measured using a manocalcimeter with $17.5 \%$ hydrochloric acid.
Three series of measurements were made (limit of error \pm $1 \%)$. Two series were performed on rock fragments, the last one on the crushed homogenised stock.

The mineralogy of the bulk rock has been performed by X-ray diffraction (XRD; Siemens D500) on powder after a moderate crushing. The diffractograms were interpreted manually according to the conventional method.
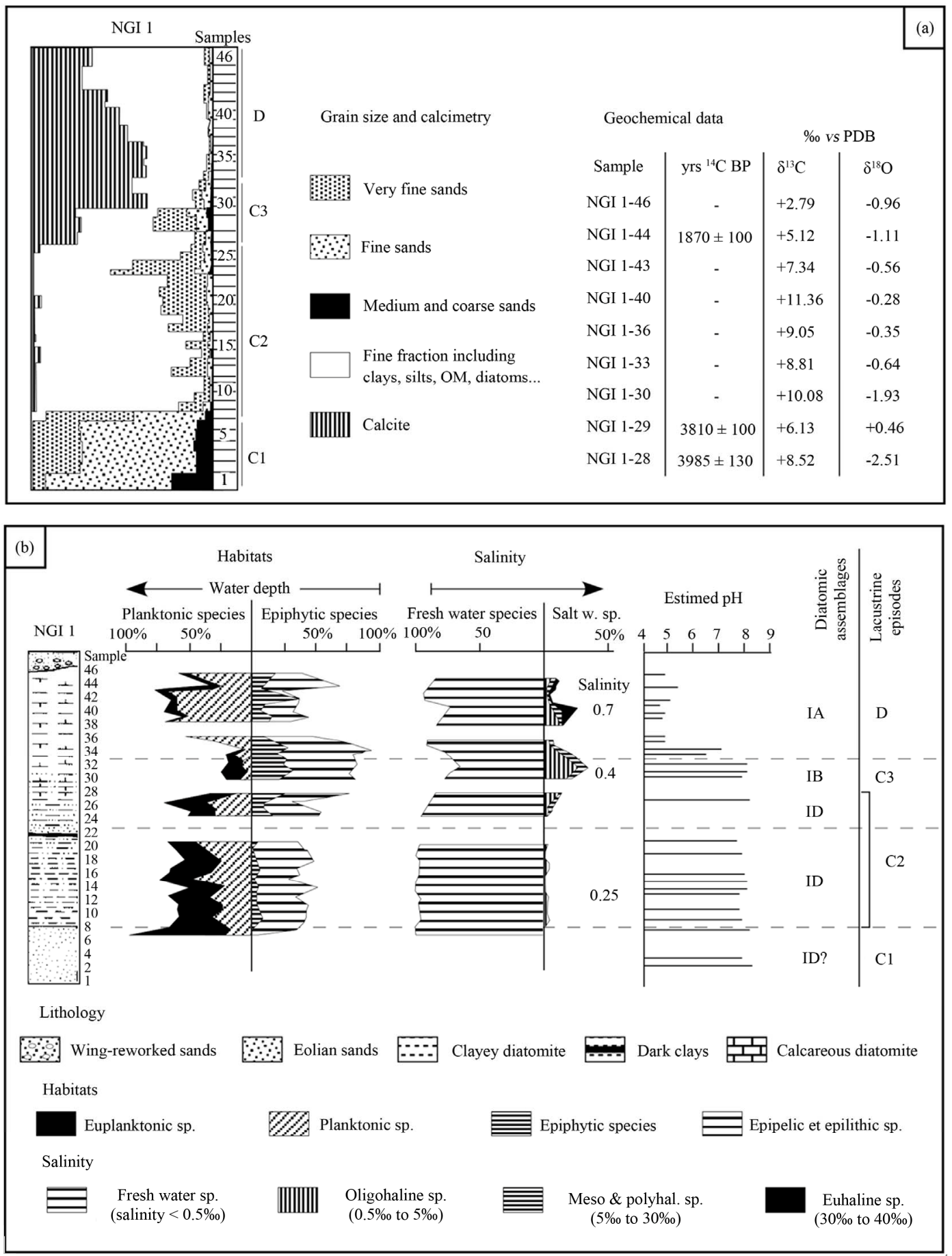

Figure 3. Previous studies of NGI-1 section. A. Sedimentological and geochemical results (Durand, 1995). B. Paleoenvironmental reconstruction based on diatoms (Gasse, 1987). 
The diffractometric spectrum of amorphous silica (opal A) was comparable with a convexity of the base line between $15^{\circ}$ and $32^{\circ}$. The semi-quantitative estimations are based on the major peak heights and areas summed to $100 \%$, with the relative error being $\pm 5 \%$.

The clay mineral $(<2 \mu \mathrm{m})$ assemblages were studied using X-ray diffraction on oriented mounts after decalcification. For each sample, three analyses were performed after: air-drying, a polyalcohol solvation, and heating at $480^{\circ} \mathrm{C}$ for 3 hours. The clay mineral identification was done according to the position of the (001) series of basal reflections on the three diffractograms [26]. The semiquantitative estimations, which are used to characterize the clay mineral assemblage, are based on the peak heights and areas summed to $100 \%$, with the relative error being $\pm 5 \%$. In the domain of small angles, the spectrum is rather indistinct and appears only as a convexity of the base line between $4.5^{\circ}$ and $6.5^{\circ}$ (19.6 to $13.5 \AA$ ). This character results from the low crystallinity of smectite and/or interstratified clay minerals [27], and therefore has not been distinguished.

The sandy particles were studied with a binocular magnifying glass and an optical microscope. Additionnal data were obtained by scanning electron microscope (FESEM, JEOL 5400) coupled with a Link Analytical microprobe analyzer.

\section{Previous Works}

Several analyses have been made in the previous studies of two sections (NGI-1 and NGI-10): grain size and geochemical parameters (Figure 3(a)), diatom contents (Figure 3(b)), the biogeochemical properties (silica's cycle) and hydrous sodium silicates [2,5,12,22,25,28,29].

The paleobiological analysis of section NGI-1 allows recognition of several depositional environments (Figure 3(b), [5]). At the bottom (C1), only samples 2, 3 and 6 contain a diatom flora composed of four planktonic taxa, which may reflect an offshore, freshwater environment. However, reworking is suspected because of the extremely low species diversity, the exclusive presence of species with thick frustules, their occurrence in sandy deposits, and their absence in Samples 1, 4 and 5. This would rather reflect littoral conditions [5]. The C2 phase (samples 7 - 27) represents a lacustrine episode. The diatom flora reflects permanently fresh, slightly alkaline water of a shallow tropical lake. The diatom flora is very similar to that of the deposits of Arikou Kouri (Figure 1(b)), posterior to a paleosol dated from $6480 \pm 725$ yrs $14 \mathrm{C}$ BP (7100 to $3700 \mathrm{BC}$ ). N'Guigmi, as Arikou Kouri, is thus regarded to depend on the water level of the Lake Chad [5], but the high proportion of periphytic species in NGI-1 deposits indicates a relatively low water depth and the proximity of the paleoshore. Moreover, the disappea- rance of diatoms in some sandy samples (20 and 22 to 24) reflects short dry phases.

The C3 phase (Samples 28 - 32) registered a drop in water level shown by the oscillating and increasing frequency of the periphytic forms, which may develop in slightly stratified swamps. The salinity regulation characteristic of Phase 2 was no longer maintained. The environment evolved into a poorly layered swamp with a high biological activity, dating around $3985 \pm 130$ yrs 14C BP (2900 to $2100 \mathrm{BC}$ ).

Thereafter (Phase D), the waters became stratified with acidic conditions on the bottom ( $\mathrm{pH} 4.5$ to 5). The diatom assemblage show the instability of this waterbody with enormous short-term fluctuations and brief alkalinesaline phases until the final drying after $1800 \pm 100 \mathrm{yrs}$ 14C BP (60 BC to $460 \mathrm{AD}$; [22]). The diatom flora of NGI-10 section is closely comparable to the D phase of NGI-1 section [22].

\section{Analyses and Interpretations}

\subsection{Mineralogical Analysis}

In the NGI-1 section, the main constituents are quartz, calcite, amorphous silica, and clay minerals (Figure 4). This reduced paragenesis is explained by the high solubility of evaporitic salts [30]. Only calcite, amorphous silica and clay minerals can resist the infiltrations of meteoric waters and successive flooding of the interdune depression.

The abundance of quartz varies along the sedimentary profile (NGI-1 section): major component of the core bottom (Samples 3, 6 and 7), its proportions gradually decreasing in the overlying samples, despite of some localised increases (Samples 22 to 24 and 29). The spectrum of amorphous silica is present on almost all the diffractograms, but it strongly decreases for samples 22, 24, 28, 29, 30 and 32 .

The carbonates (i.e. calcite) are absent at the bottom of the section, in small proportions $(10 \%$ to $15 \%)$ between Samples 14 and 22, and disappear for Samples 23 to 27 (Figure 4). They reappear in sample 28 (35\%), increasing up to $75 \%$ of the sediment in Sample 31, and then decreasing regularly (30\% to $40 \%$ ) towards the top of the profile. The repeated measurements are very close, except for the Samples 14 to 20 and 24 to 29. For this latter, the differences can be very large (e.g. Sample 29: $71 \%, 27 \%$ and $0 \%$ ).

The magadiite spectrum was confidently identified only in the NGI-10 section. Icole et al. [29] have already shown that this mineral is the main component of silicate concretions. The magadiite also occurs as scattered crystals within the clayey calcareous deposits (Sebag et al., 2001). The presence of magadiite within the lacustrine sediments provides significant paleoecological informa- 


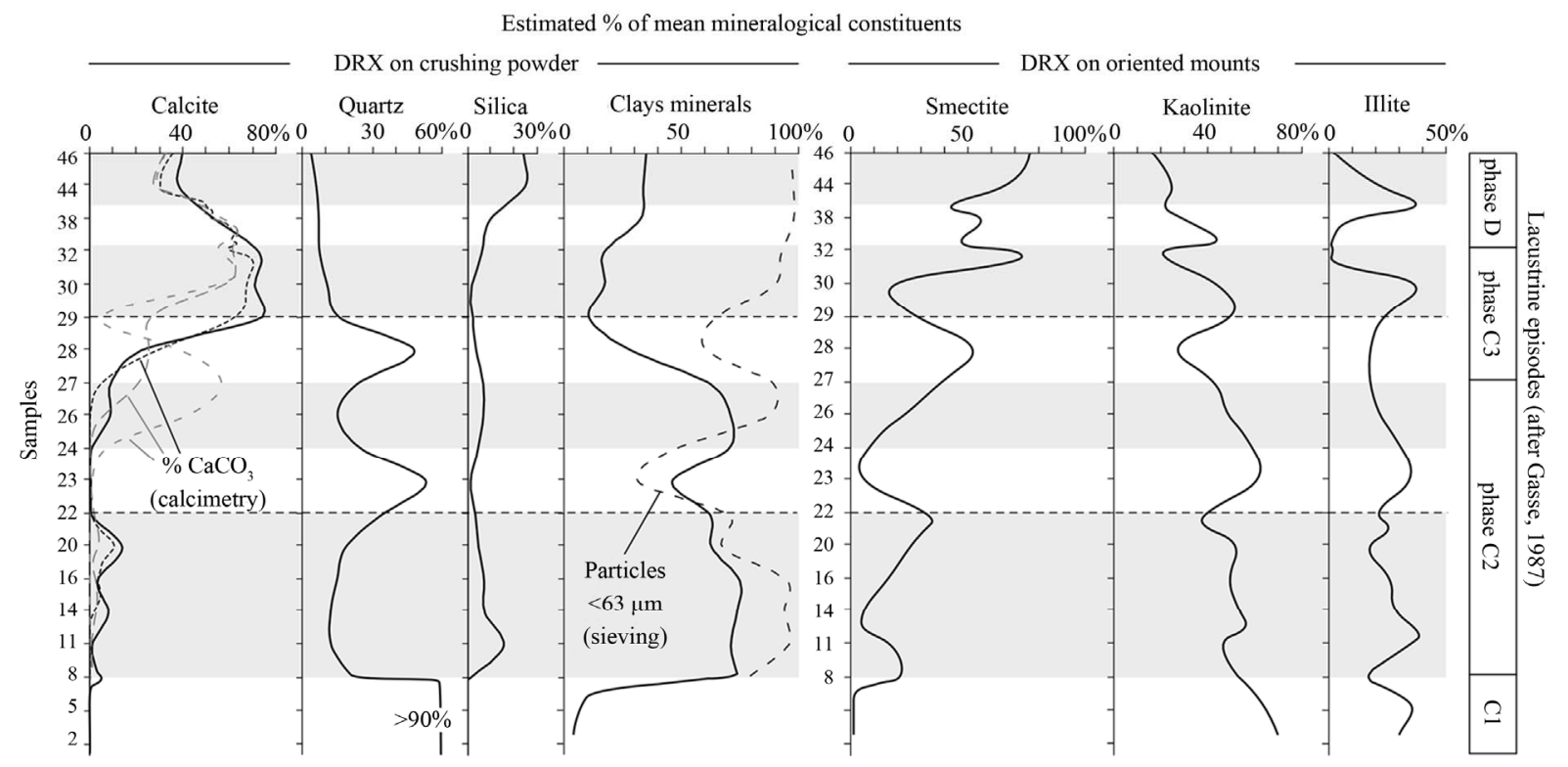

Figure 4. Variations of the main mineralogical components: results from semi-quantitative XRD performed on disorientated powder and oriented mounts.

tion: sodium carbonate-bicarbonate facies of parent solutions, highly dissolved silica contents, $\mathrm{pH}$ variations by seasonal dilution, or organic matter diagenesis [25,31].

\subsection{Nature and Origin of Coarse Fractions}

The sandy particles $(>63 \mu \mathrm{m})$ group two stocks: aeolian quartz and lacustrine particles (i.e. aggregates, bioclasts; Plate 1). The silty particles regroup quartz grains, Diatom frustules, and bioclasts.

The omnipresence of quartz is related to the nature of the substratum (i.e. sand dunes) and aeolian allochthonous input. Quartz is thus almost exclusively of wind origin, either directly trapped in the interdune depression (i.e. aeolian deposition), or indirectly, due to reworking from the dune slope (i.e. runoff). On the other hand, SEM observations confirm some quartz authigenesis in an apolyhaline environment (Plate 1; [28]).

The diatom frustules explain the presence of amorphous silica in the palustro-lacustrine deposits.

However, many silicified plant fragments were identified in the calcareous sediments (Plate 1). In this apolyhaline environment, the amorphous silica controls the autochthonous sedimentation: sodium silicates [25,30,32], clay neogenesis [33,34], biogenic mineralizations [35], and silicification processes [36,37].

Two types of aggregates were observed: cemented grains and bio-aggregates (Plate 1). The cemented grains include sandy quartz grains cemented by hardened Ferich material. This cement reflects geochemical dynamics related to runoff [38] or to microbial activity $[39,40]$. The bio-aggregates are constituted by silty and sandy detrital particles (quartz grains, bioclasts) trapped by organic fi- laments or biofilms (Plate 1). These bioaggregates are always present in the sieving residues and can entirely comprise the coarsest sands (e.g. Sample 19). Cell clusters are associated with filaments and biofilms, and present similarities with cyanobacteria taxa (Chrooccocalae, Pleurocapsaleae).

\subsection{Nature and Origin of Fine Fraction}

In the studied area, clay minerals can be of various origins: 1) as a significant fraction of aeolian dust, their mineralogy reflects the geology of their source areas. Schematically, illite and chlorite minerals dominated the dust deposited in the Atlantic when it came from the northwestern Sahara, and kaolinite dominated when the dust came from the southern Sahara and the Sahel [41-43]. Thus, in the area of Niamey $\left(13^{\circ} 40^{\prime} \mathrm{N}, 1^{\circ} 47^{\prime} \mathrm{E}\right.$, western Niger, Sahel), kaolinite dominates the clay assemblage from present-day dust with small occasional contributions of smectite and traces of illite (Drees et al., 1993). Further to the south, kaolinite dominates the clay assemblage from the present-day dust in the upstream basin of the Yobe River (northern Nigeria, Sudan zone; [44]).

2) The Lake Chad constitutes another regional source of detrital clays. Clay minerals are primarily transported to the lacustrine domain by the Chari River, whose mean annual sediment load is composed of $38 \%$ kaolinite, $11 \%$ illite, and $10 \%$ smectite [45]. However, the lacustrine domain also constitutes an environment of significant geochemical transformations such as neogenesis of smectite minerals; neogenetic smectites represent $65.50 \%$ of clay assemblages in the lacustrine sediments [45]. The mean composition of the lacustrine sediments (kaolinite 26\%, 

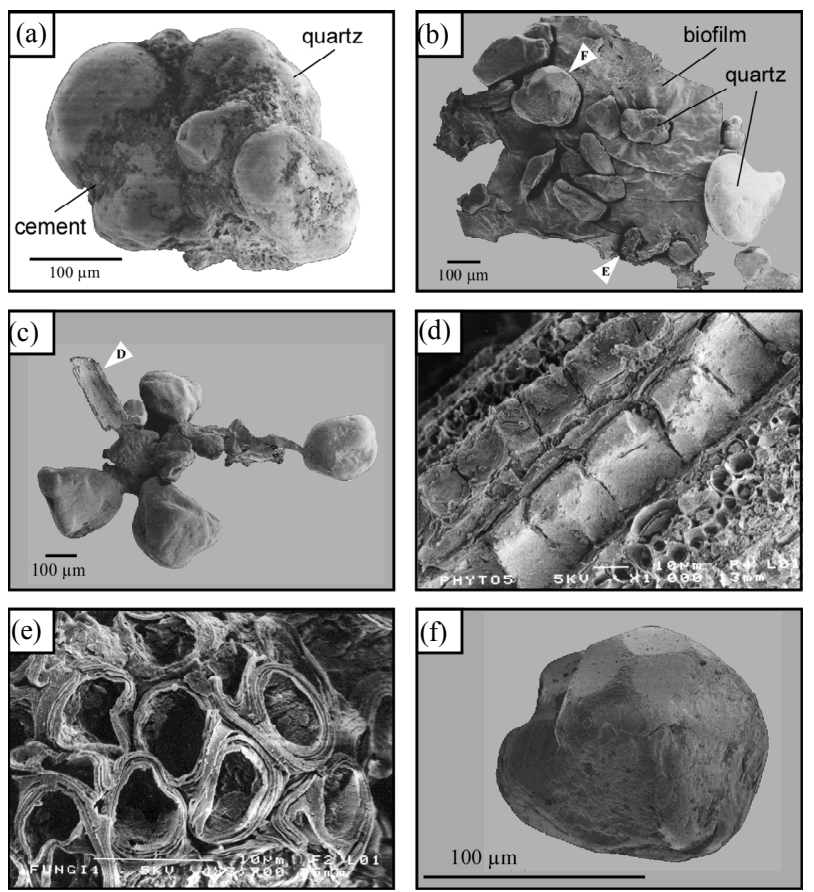

Plate 1. Some SEM observation of sandy and silty fractions. (a) to (c) Examples of cemeted grain and bio-aggregats. (d) to (f) Close-up of (b) and (c). (f) Quartz showing neogenesis in lacustrine environment.

illite $8 \%$, smectite $20 \%$ ) thus differs from those of the Chari inputs, but the mean kaolinite/illite ratio is (around 3.4; preserved [45]).

This difference between detrital and neogenetic clay minerals has been observed in the Holocene interdune lakes and ponds in the studied area. In the West-Termit depression $\left(16^{\circ} 03^{\prime} \mathrm{N}, 11^{\circ} 15^{\prime} \mathrm{E}\right.$, northern Manga) located at the bottom of a Meso-Cenozoic horst (i.e. Termit Massif), the lacustrine deposits contain kaolinite, illite, and smectite in variable proportions according to the hydroclimatic context $[16,17,46]$. Runoff erosion on the massif exclusively provides kaolinite and illite. During the Wet Maximum of the Early Holocene, whereas the plant cover development prevented such runoff inputs from the massif, the West-Termit depression collected aeolian dust almost exclusively composed of kaolinite-type minerals $[16,17]$. If smectites of some sediment layers seem related to dust input, they are mainly neogenetic in the samples where their content is the highest $[16,17]$.

To the north, a similar distribution of clay assemblages was observed in paleosols of the Tenere between $17^{\circ} 30^{\prime} \mathrm{N}$ and $20^{\circ} \mathrm{N}$ [47]. Generally, the paleosols on the ante-Neolithic aeolian sandy deposits are richer in illite and kaolinite, whereas the hydromorphic soils developed in lacustrine depressions are richer in smectite [47].

To the South, the Bougdouma interdune depression $\left(13^{\circ} 19^{\prime} \mathrm{N}, 11^{\circ} 40^{\prime} \mathrm{E}\right.$, southern Manga) constitutes a closed basin whose watershed is limited to the sandy dune slopes. Because of the high groundwater level, the lacustrine environment remained during the Holocene [13]. Smectite minerals always dominate (up to $80 \%$ ) the clay assemblages, whereas kaolinite is relatively abundant only in samples richer in quartz $[13,16,17,46]$. Nevertheless, it seems that kaolinite is related to aeolian dynamics and the smectite to the neogenesis. Generally, two neogenesis processes can occur in interdune lakes. The first one is purely chemical, and results from concentration of lacustrine waters related to intense evaporation [48,49]. The second process is mainly biochemical and related to biogenic amorphous silica (i.e. frustules) and brackish solutions [33,34].

In the N'Guigmi depression (i.e. NGI-1 section), the relative kaolinite and illite contents, on the one hand, and the smectite content, on the other hand, vary inversely which suggests two distinct dynamics. More precisely, the kaolinite/illite ratio varies from 0.5 to 21 , and is about 2 in the basal sandy deposits (Samples 1 to 6). However, several samples present the same ratio values of about 2 : Samples 12 to 14 (low smectite content), and Samples 23, 29 and 30 (low smectite content and high quartz content). Moreover, the results show increasing smectite contents for fining-up sequences, and their absence in sandy samples. This absence must be noted, because smectite minerals are always present in the Lake Chad deposits; in the zone nearest to N'Guigmi, they always represent double the illite content [45].

Regarding the present-day and Holocene regional contexts, it seems possible to interpret the unusual "kaolinite + illite vs smectite" antagonism in the NGI-1 section. Kaolinite and illite minerals are originally detrital: transported in aeolian dust, they are directly deposited in the interdune lake, or flattened on the ground by rainfall, and runoff-reworked into the depression. These runoff dynamics are made possible because of cryptogamic crust [50,51] that can be formed in humid context and leave bioaggregats in sediments (Plate 1). Therefore the interdune depression constitutes a "decantation basin" for detrital clay minerals [48]. Smectite and interstratified minerals missing in the sandy substratum constitute an indigenous neogenic fraction. The interdune lake also can function as a "biogeochemical reactor" [48].

\subsection{Distribution of Calcium Carbonates}

In the area studied, the calcareous particulate inputs are negligible. The only calcium sources are the regional groundwater [52] or local infiltrations of Lake Chad waters through dune sands [53]. The calcite distribution shows a lithological limit between Samples 27 and 28 (Figure 4). In the clayey samples, the differences between the three measurements imply very localised precipitation processes: 1) by capillary suction in interdunal deposits 
after the drying phase, 2) bio-induced precipitation, or 3) biogenic mineralisations. In the Samples 14 to 20, the calcite precipitates as cement coatings in horizontal and planar pores. Thus, calcite precipitation can be related 1) to evaporatic crystallisation during deposition (syngenetic inorganic calcite), or 2) to a groundwater level fall during a prolonged drying after deposition (diagenetic inorganic calcite). In addition, many calcareous root tubules were observed in Samples 27 to 29. They result from biochemical processes affecting the interstitial solutions (bio-induced carbonates). Thus, these carbonates form slightly later than the sediment deposition. In samples 30 to 46 , the calcium carbonates constitute a major constituent: calcite crystallisation is directly related to the interdunal sedimentary dynamics (syngenetic inorganic calcite).

\section{Discussion}

\subsection{Model and Paleoclimatology}

Because of their characteristics (i.e. endoreism, water inputs and discharges), the interdunal lakes can be looked upon as geosystems, whose sedimentary dynamics depend mainly on boundary conditions (i.e. climate, geomorphology, hydrology). Thus, it is possible to model these sedimentary dynamics according to various external forcing parameters (e.g. rainfall, evaporation, nature and concentration of waters, biological activities). Three sedimentary dynamics and three basin types were distinguished: 1) decantation of aeolian inputs (decantation basin), 2) neogenesis of clay minerals (biogeochemical reactor), and 3) physicochemical precipitations (physicochemical reactor). Carmouze and Pedro [48] proposed an analogical model of Lake Chad dynamics, which can explain these observations (Figure 5).

In the proposed model, sedimentary dynamics of interdunal lakes is controlled by the antagonistic actions of two forcing parameters. The hydro-climatic forcing reflects the hydrological balance (rainfall, evaporation, phreatic inflow, infiltrations). This parameter can be quantified using the ionic concentration of water bodies. The biogeochemical forcing reflects the losses in dissolved species, and results from the whole of the sedimentary processes contributing to physicochemical and/or biochemical sedimentation.

Decantation basin: the wet climatic phases (rainfall/ evaporation $>1$ ) induce decreasing ionic concentration (i.e. water dilution) and modify the impact of the biogeochemical forcing (i.e. increasing the water amounts). The related deposits are characterized by detrital clayey silty sediments (i.e. aeolian inputs) and are dominated by quartz, kaolinite and illite.

Physicochemical or evaporitic reactor: the arid phases $(\mathrm{R} / \mathrm{E}<1)$ induce decreasing biogeochemical neogenesis (high ionic concentration). The detrital fluxes increase, but aeolian inputs are easily reworked (low water area, drying episodes). On the other hand, the ionic concentration can strongly increase under climatic control (i.e. intense evaporation). Consequently, sedimentary dynamoics become mainly physicochemical leading to evaporitic deposition of carbonates, sulphates, and sodium silicates in shallow water environments. However, high solubility of evaporitic salts favours their dissolution by later meteoric infiltrations and flooding phases.

Biogeochemical reactor: in an intermediate climatic context $(\mathrm{R} / \mathrm{E}=1)$, the rainfalls are sufficient to maintain a relative dilution of water bodies, and inhibit physicochemical precipitations. This climatic context also induces a relative decrease in aeolian fluxes at a regional scale (i.e. low deflation). In these conditions (i.e. low ionic concentration, low detrital inputs), the sedimentary dynamics are related to the biogeochemical processes, such as biogenic and bio-induced mineralisation (i.e. tests, shells, phytoliths, root tubules) and clay mineral neogenesis from biogenic amorphous silica [28]. The clayey silty deposits include detrital (i.e. quartz, kaolinite, illite), neogenic (i.e. smectite, calcite, amorphous silica), and possible evaporitic components (i.e. sodium silicates, sulphates, desiccation cracks).

These general trends must be moderated. Indeed, a seasonal control adds to the climatic control previously described, and can impact the long-term evolution of interdunal geosystems. For example, in a stable climatic context at a centennial range, an annual hydrological balance staying slightly negative can induce progressive evolution from a decantation basin to a biogeochemical reactor, and then to an evaporitic reactor. Moreover, seasonal alternances modify the sedimentary dynamics and induce mixed sources in interdunal lacustrine deposits: runoff-reworked sediments during the rainfalls, increasing biogeochemical processes after the rainy season, increasing eolian fluxes and evaporitic precipitation during the dry season. On the other hand, these micro-geosystems are particularly sensitive to threshold, inertia and oasis effects [54]. Nevertheless, the analogical model allows the replacement of the sedimentological features of interdunal deposits in a paleohydrological context, and to interpret the mineralogical variations in term of paleoenvironmental changes.

\subsection{Depositional Environments}

Interpreted within this proposed framework, the sedimentological variations reflect the succession of the depositional environments related to local climato-hydrological changes. The successive steps of N'Guigmi lake history can be thus reconstituted (Figure 6).

Aeolian deposition in an arid context: the NGI-1 core 


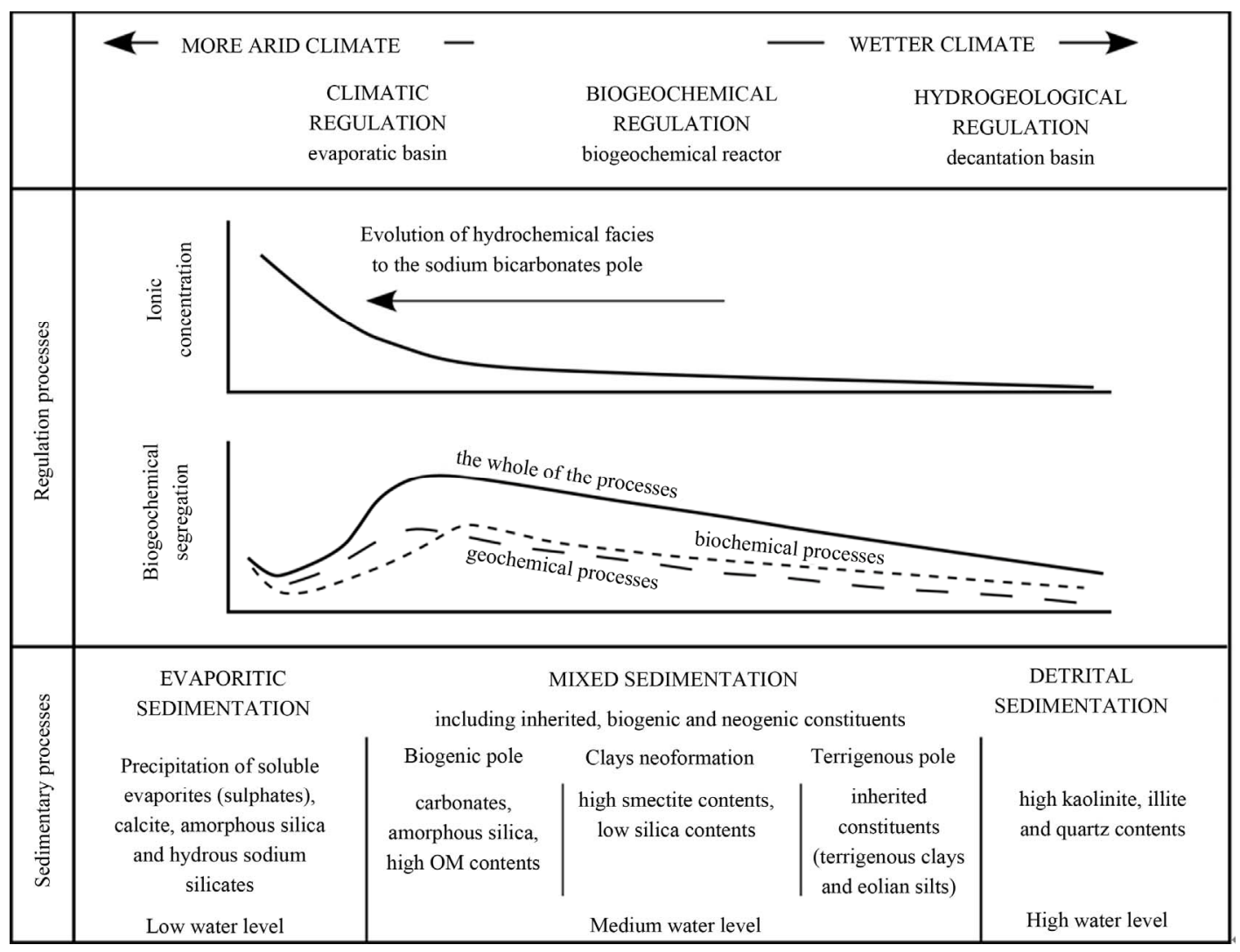

Figure 5. Sedimentary dynamics in interdune lakes (modified after Carmouze \& Pedro, 1977).

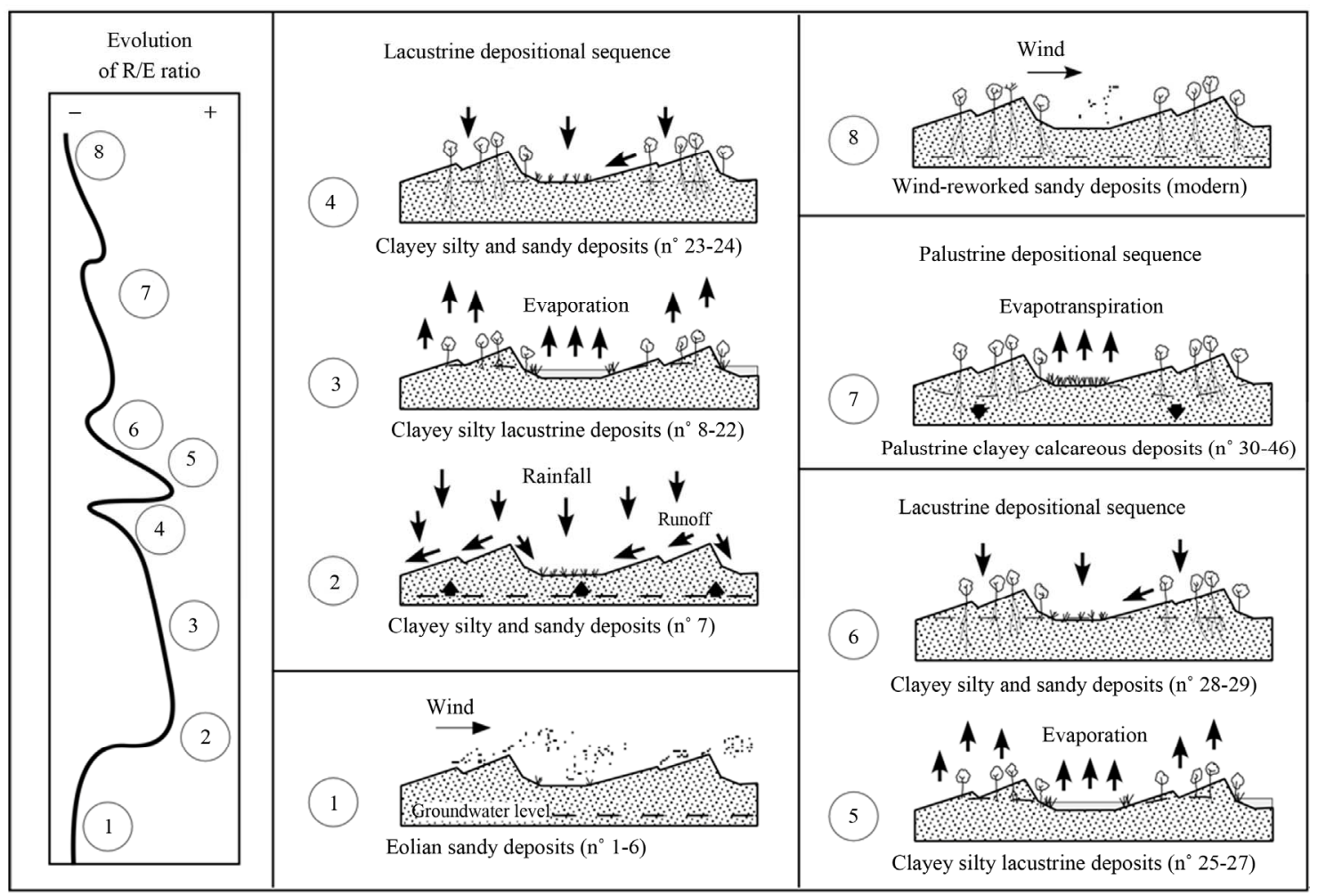

Figure 6. Evolution of depositional environments in N'Guigmi depression established using sedimentological and mineralogical data from Holocene deposits. 
bottom (Samples 1 to 6) corresponds to the top of the substratum of the interdunal deposits (i.e. sandy erg). The first deposits result from an aeolian sandy sedimentation in a strictly arid context [22]. The clay contents are very low, and smectites are trace amounts. This is in contradiction with aquatic dynamics. Moreover, diatoms are certainly reworked [5] insofar as Tardiglacial and Lower Holocene lacustrine deposits are nearly abundant (lacustrine beaches; Figure 1). For example, some diatomitic deposits dated at $8580 \pm 140$ yrs $14 \mathrm{C} \mathrm{BP}$ (8200 to 7300 BC) outcrop at the surface about $2 \mathrm{~km}$ to the south from NGI-1 [20]. The Samples 1 to 6 record an aeolian sedimentation, and are constituted by wind-reworked Kanemian aeolian sands.

Lacustrine environments (surficial inflow): the first significant detrital clay minerals were identified at the bottom of the lower clayey diatomite (Sample 7). They are related to water-dominated deposition (i.e. rainfall, runoff). The following deposits (Samples 8 to 22) reflect the oscillations of an interdune lake between detrital and biogeochemical poles. During this period, the sedimentary sequence recorded brief dry episodes in the diatomic flora [5] as well as in lithological features (e.g. millimetre lamination in clayey diatomite). However, these episodes reflect short-term variations of the hydrological balance. They are probably related to secular dry periods and thus do not reflect the general climatic changes. On the other hand, the Samples 23 and 24 include clayey silty and sandy grain sizes, but do not show laminated structures. They consist of lacustrine and reworked sediments. Thus, although their formation is related to flooding, they reflect a prior dry period, and mark the end of an initial lacustrine sequence boundary. The higher clayey diatomite replicates the previous lacustrine sequence. Samples 25 to 27 were deposited in a lacustrine environment supplied by runoff during the rainy season, and by groundwater reservoir during the dry season. However, the interdunal lake recorded frequent dry episodes, which reflect a more arid climate. Samples 28 - 29 present the same characteritics as those of Samples 23 - 24. They reflect a prolonged dry period and mark the second lacustrine sequence boundary.

Palustrine environments (groundwater inflow): the clayey calcareous diatomites reflect oscillations between biogeochemical and physico-chemical poles. The production of inorganic calcite (up to 70\%) marks a significant hydrological change in the interdunal geosystem. Samples 30 to 46 are related to a palustrine environment (i.e. shallow water, hygrophytes) supplied by the Manga groundwater aquifer or infiltrations of Lake Chad waters. This hydrological context could be related to the previous wetter period, which induced the progressive recharge of water storage (i.e. inertia and oasis effects; [54]). The sedimentary dynamics are controlled by evaporitic water concentration, thus indicating a more arid climate. Compared to the previous deposits, the quasi-absence of sandy grains $(<5 \%)$ confirms the de- creasing rainfall (i.e. weak runoff). In addition, these clayey calcareous diatomites show characteristic drying structures (e.g. desiccation cracks) and evaporatic mineral species (i.e. carbonate cements, sodium silicates). The lowering of groundwater levels related to these dry episodes could explain the carbonate content in Samples 14 to 21 and 27 to 30, where their sedimentological parameters reflect a wet climate.

Sub-present aeolian deposition: the top sandy deposits mark the final interdunal drying and the settlement of arid climatic conditions. These sediments result from reworked Kanemian deposits and aeolian inputs.

This sedimentological approach allows the evolution to be drawn for the local climato-hydrological conditions during the Late Holocene (Figure 6). We note that the plot tends "to accelerate" the evolutions towards the detrital pole because of weaker sedimentation rates during the wet phases. In addition, the threshold, inertia and oasis effects can influence the interpretation (Durand \& Lang, 1986). For example, the effect of arid episodes is mitigated by large hydrological reservoirs (i.e. phreatic groundwater, Lake Chad).

With regard to the radiometric ages, two cases must be considered. The calcite in most recent deposits is related to an evaporitic crystallisation directly from lacustrine waters: the measurement is therefore related to the deposition age (Sample 44: $1870 \pm 100$ yrs 14C BP). On the other hand, other measurements (Sample 28: $3985 \pm 130$ yrs 14C BP; Sample 29: $3810 \pm 100$ yrs 14C BP) are slightly younger because of post-deposition carbonates (i.e. root tubules).

\section{Conclusions}

The sedimentological analysis complements the results of the paleobiological analysis in several points. First, about the chronology, several differences are documented between the diatom evolution and the sedimentary record. For example, major lacustrine episodes seem more restricted in sedimentary information: they begin only from Sample 7 and finish before $3985 \pm 130$ yrs 14C BP (2900 to $2100 \mathrm{BC}$ ). In addition, the sedimentological analysis clarifies the heterogeneity of phase C2 that includes two lacustrine sequences separated by a drying phase (Samples 23 - 24; Sequence 4, Figure 6). This stratigraphical break is more significant than the short dry phases deduced from the absence of diatoms ([5] Figure 3(b)). Moreover, in a more precarious hydroclimatic context (Taoudenni, North Mali; 22 to $23^{\circ} \mathrm{N}$ ), up to 9 transgression/regression sequences have been documented between ca 6700 and 3900 yrs 14C BP [55]. A phase of deflation and aeolian accumulation was also recorded be- 
tween 6000 and 5500 yrs $14 \mathrm{C}$ BP [55]. In Western Niger $\left(17^{\circ} 80^{\prime} \mathrm{N}, 4040^{\prime} \mathrm{E}\right)$, a phase of deflation and aeolian accumulation was also dated between ca 5800 and $5400 \mathrm{yrs}$ 14C BP [56]. It seems possible to propose a correlation between this more arid period and the drying during phase C2 in the NGI-1 section.

Second, sediment origins, particularly for clay minerals, provide new information to specify sedimentary dynamics in the lacustrine environment. Infiltrations of lacustrine waters are possible through aeolian sandy formations (i.e. peri-lacustrine dune ridge) that separate the N'Guigmi basin and the Lake Chad domain (Figure 1). On the other hand, the small amount of smectites, which are abundant in Lake Chad, reflects the poverty and even the absence of direct inputs from the lacustrine waters. Hence, this implies the absence of direct connection between the N'Guigmi basin and Lake Chad. The diatom flora in phase C2 of the NGI-1 section and in Arikou Kouri deposits are similar [5]. This can be explained by the concurrent events in environments that are close not only geographically but also in terms of hydro-climatic conditions.

Latter on, the lateral disappearance of the basal clayey deposits of the phase $\mathrm{C} 2$ at about $285 \mathrm{~m}$ asl is a pertinent paleogeographical indicator. Taking into account the present-day topography, with a lacustrine level at $285 \mathrm{~m}$ a.s.l., the northern part of Lake Chad would have had $>10 \mathrm{~m}$ of water filling the deepest interdunal hollows of the Kanemian erg. In addition, $>90 \%$ of the northern part of the Lake Chad would have $>5 \mathrm{~m}$. Resting against the perilacustrine dune ridge, the Arikou Kouri zone (Figure 1(b)) would have formed part of a large tropical lake [5]. In the N'Guigmi region, the banks of such a lake would not have been much different than those observed before 1973. It would have been limited by the perilacustrine dune ridge except near the Chad border where this bar is not continuous (Figure 1(b)).

The relationships between the environmental evolution and the dust deposition have been debated for a long time [41]. In this respect, the closed lakes and swamps of the Sahel provide excellent records. However, a methodological problem remains. It is not possible to consider that the dust is constitued by the fraction $<63 \mu \mathrm{m}$, free of carbonates, salts, oxides and biogenic opal as has been suggested recently for meridional Manga in Nigeria [14]. The past and present-day Sahara dust can include a component of nearby origin (proximal dust) of the size of very fine sand (63 to $125 \mu \mathrm{m} ; 16,44$, and 57). Above all, they can contain a large clay fraction. This $<2 \mu \mathrm{m}$ fraction can reach $62 \%$ for present-day dust in Nigeria, even if it generally ranges between $10 \%$ and $30 \%$ [44,57,58]. Whereas, it has just been demonstrated that authigenic smectite can form in these closed lakes. The problem is so complicated that these authigenic smectites can also be removed by deflation during drying phases and the latter behave as proximal dust. The use of the grain size distributions to distinguish various stocks of dust deposits using their unimodal distribution is certainly an interesting approach, considering that the non-clayey detrital fraction is representative of all the dust $[16,41,46,57]$. The use of a clay mineral index, e.g. "smectite vs illite/kaolinite", could be an interesting complementary approach.

\section{Acknowledgements}

This study was supported by the AIRD (Agence Interétablissements de Recherche pour le Développement) through the CORUS2 project entitled "Impact de la pression anthropique et du Changement Global sur les flux sédimentaires en zone sahélienne" (Grant No. 6116). It is also a contribution to the AMEDE action (Analyse Multi-Echelle de la Dynamique Eolienne au Sahel) funded by the SFR SCALE (ESTER project) with support from the Institut de Recherche pour le Dévelopement (IRD) and the Région Haute-Normandie (France). The authors would like to thank the "AIRE_-Dévelopement" Program (MAE France) and "ROSELT/OSS - Niger" Project for funding of two field missions.

\section{REFERENCES}

[1] H. Faure, "Reconnaissance Géologique des Formations Sédimentaires Post-Paléozoïques du Niger Oriental," Doctorat d'Etat Thesis, University of Paris, and Mém. BRGM 47, 1962.

[2] A. Durand, "Sédiments Quaternaires et Changements Climatiques au Sahel Central (Niger et Tchad)," African Geoscience Review, Vol. 2, No. 3-4, 1995, pp. 323-614.

[3] H. Faure, E. Manguin and R. Nydal, "Formations Lacustres du Quaternaire Supérieur du Niger Oriental: Diatomites et Âges Absolus," Bullutin BRGM, Vol. 3, No. 1, 1963, pp. 41-63.

[4] M. Servant and S. Servant, "Les Formations Lacustres et les Diatomées du Quaternaire Recent du Fond de la $\mathrm{Cu}$ vette Tchadienne," Review of Géograpghy Physical Géological Dynamics, Vol. 12, No. 1, 1970, pp. 63-73.

[5] F. Gasse, "Diatoms for Reconstructing Palaeoenvironnements and Paleohydrology in Tropical Semi-Arid Zones. Example of Some Lakes from Niger since 12000 BP," Hydrobiologia, Vol. 154, No. 1, 1987, pp. 127-163. doi:10.1007/BF00026837

[6] J. Malley, "Etudes Palynologiques dans le Bassin du Tchad et Paléoclimatologie de l'Afrique Nord-Tropicale de 30,000 ans à L'Époque Actuelle,” 1981.

[7] U. Salzmann and M. Waller, "The Holocene Vegetational History of the Nigerian Sahel Based on Multiple Pollen Profiles," Review of Palaeobotany and Palynology, Vol. 100, No. 1-2, 1998, pp. 39-72. doi:10.1016/S0034-6667(97)00053-5

[8] J. A. Holmes, F. A. Street-Perrott, M. J. Allen, P. A. Fothergill, D. D. Harkness, D. Kroon and R. A. Perrott, "Ho- 
locene Palaeolimnology of Kajemarum Oasis, Northern Nigeria: An Isotopic Study of Ostracods, Bulk Carbonate and Organic Carbon," Journal of Geological Science, Vol. 154, No. 2, 1997, pp. 311-319. doi:10.1144/gsigs.154.2.0311

[9] J. A. Holmes, M. J. Allen, F. A. Street-Perrott, M. Ivanovich, R. A. Perrott and M. P. Walker, "Late Holocene Palaeolimnology of Bal Lake, Northern Nigeria, a Multidisciplinary Study," Palaeogeography, Palaeogeography, Palaeoclimatology, Vol. 148, No. 1-3, 1999, pp. 169-185. doi:10.1016/S0031-0182(98)00182-5

[10] U. Salzmann, P. Hoelzmann and I. Morczinek, "Late Quaternary Climate and Vegetation of the Sudanian Zone of Northeast Nigeria," Quaternary Research, Vol. 58, No. 1, 2002, pp. 73-83. doi:10.1006/qres.2002.2356

[11] J. A. Holmes, P. A. Fothergill, F. A. Street-Perrott, R. A. Perrott, "A High-Resolution Holocene Ostracod Record from the Sahel Zone of Northeastern Nigeria," Journal of Paleolimnology, Vol. 20, No. 4, 1998, pp. 369-380. doi:10.1023/A:1007923304411

[12] F. Gasse, "Diatom-Inferred Salinity and Carbonate Oxygen Isotopes in Holocene Waterbodies of the Western Sahara and Sahel (Africa)," Quaternary Science Reviews, Vol. 21, No. 7, 2002, pp. 737-767. doi:10.1016/S0277-3791(01)00125-1

[13] R. Téhet, F. Gasse, A. Durand, P. Schroeter and J. C. Fontes, "Fluctuations Climatiques du Tardiglaciaire à l'Actuel au Sahel (Bougdouma, Niger Méridional)," Academic Science, Paris, 1990.

[14] F. A. Street-Perrott, J. A. Holmes, M. P. Waller, M. J. Allen, N. G. H. Barber, P. A. Fothergill, D. D. Harkness, M. Ivanovich, D. Kroon and R. A. Perrott, "Drought and Dust Deposition in the West African Sahel: A 5500-Year Record from Kajemarum Oasis, Northeastern Nigeria," The Holocene, Vol. 10, No. 3, 2000, pp. 293-302. doi:10.1191/095968300678141274

[15] Z. Garba, A. Durand and J. Lang, "Enregistrement Sédimentaire des Variations de la Dynamique Éolienne Pendant la Transition Tardiglaciaire/Holocène à la Limite Sahara/Sahel (Termit, Bassin du Lac Tchad)," 1996.

[16] Z. Garba, A. Durand and J. Lang, "Identification et Quantification des Dépôts de Poussières Éoliennes au Quarternaire Supérieur à la Limite Sahara/Sahel (Massif de Termit, République du Niger, Bassin du Lac Tchad),” 2000.

[17] Z. Garba, A. Durand, J. Lang and K. Alzouma, "Signification Paléoenvironnementale des Minéraux Argileux dans les Dépôts de Dépressions Fermées du Bassin du Lac Tchad au Tardiglaciaire et à l'Holocène (Termit et Bougdouma, Niger oriental)," 2003.

[18] B. Damnati, M. Taieb and D. Williamson, "Laminated Deposits from Lake Magadi (Kenya). Climatic Contrast Effect during the Maximum Wet Period between 12,000 10,000 yrs," 1992.

[19] C. Dubar, "Eléments de Paléohydrologie de l'Afrique Saharienne: Les Dépôts Quaternaires D’Origine Aquatique du Nord-Est de l'Aïr (Niger, PALHYDAF Site 3)," Ph.D. Thesis, Université de Paris Sud, Orsay, 1988.

[20] A. Durand, "Conséquences Géomorphologiques des Phéno- mènes Néotectoniques dans le Bassin du lac Tchad: Modification du Réseau Hydrographique et Origine du Pseudo-Rivage du Mégatchad dans la Région du Kadzell (République du Niger)," 1995.

[21] H. Faure and M. Servant, "Evolution Récente d'un Bassin Continental: Le Tchad-Programme D'Étude," 1970.

[22] A. Durand, J.-C. Fontes, F. Gasse, M. Icole and J. Lang, "Le Nord-Ouest du lac Tchad au Quaternaire: Étude de Paléoenvironnements Alluviaux, Éoliens, Palustres et Lacustres," Paleoecology of Africa, Vol. 16, 1984, pp. 215243.

[23] S. Mugnier, "Pluviométrie Journalière et Types de Pluies au Sahel Central: Manga et Bornu (Niger et Nigéria). Evolution de 1950 à 1990. MSc.," Centre de Recherches de Climatologie, Université de Bourgogne, Dijon, 1995.

[24] C. Riou, "La Détermination Pratique de L'Évaporation Application à l'Afrique Centrale. Mémoires ORSTOM," 1975.

[25] D. Sebag, E. P. Verrecchia, L. Seong-Joo and A. Durand, "The Natural Hydrous Sodium Silicates from the Northern Bank of Lake Chad: Occurrence, Petrology and Genesis," Sedimentary Geology, Vol. 139, No. 1, 2001, pp. 1531. doi:10.1016/S0037-0738(00)00152-4

[26] G. W. Brindley and G. Brown, "Crystal Structure of Clay Minerals and Their X-Ray Identification," Mineralogical Society, London, 1980.

[27] P.-E. Biscaye, "Mineralogy and Sedimentation of Recent Deep-Sea Clay in the Atlantic Ocean and Adjacent Seas and Oceans," Geological Society of America Bulletin, Vol. 76, No. 7, 1965, pp. 803-832. doi:10.1130/0016-7606(1965)76[803:MASORD]2.0.CO; 2

[28] D. Sebag, E. P. Verrecchia and A. Durand, "Biogeochemical Cycle of Silica in an Apolyhaline Interdunal Holocene Lake (Chad, N'Guigmi Region, Niger)," Natürwissenschaften, Vol. 86, No. 10, 1999, pp. 475-478. doi: $10.1007 / \mathrm{s} 001140050657$

[29] M. Icole, A. Durand, G. Perinet and R. Lafont, "Les Silicates de Sodium du Manga (Niger), Marqueurs de Paleoenvironnement?" Palaeogeography, Palaeoclimatology, Palaeoecology, Vol. 42, No. 3-4, 1983, pp. 273-284. doi:10.1016/0031-0182(83)90026-3

[30] G. Maglione, "Géochimie des Évaporites et Silicates Néoformés en Milieu Continental Confiné. Les Dépressions Interdunaires du Tchad," 1976.

[31] H. Eugster, "Hydrous Sodium Silicates from Lake Magadi, Kenya: Precursor of Bedded Cherts," Science, Vol. 157, No. 3793, 1967, pp. 1177-1180. doi:10.1126/science.157.3793.1177

[32] G. Maglione, Y. Tardy, "Néoformation Pédogénétique d'une Zéolite, la Mordénite, Associée aux Carbonates de Sodium dans une Dépression Interdunaire (Nord du lac Tchad)," Comptes Rendus de l'Académie des Science, Paris, Vol. 272, 1971, pp. 772-774.

[33] H. Chamley and G. Millot, "Néoformation de Montmorillonite à Partir de Diatomées et de Cendres Dans les Sédiments Marins de Santorin (Méditerranée Orientale)," Comptes Rendus de l'Académie des Science, Paris, Vol. 
274, 1972, pp. 1132-1134.

[34] D. Badaut, F. Risacher, H. Paquet, J.-P. Eberhart and F. Weber, "Néoformation de Minéraux Argileux à Partir de Frustules de Diatomées : Le cas des Lacs de L'Altiplano Bolivien," Comptes Rendus de l'Académie des Science, Paris, Vol. 289, 1979, pp. 1191-1193.

[35] H. Erhart, "Itinéraires Géochimiques et Cycle Géologique du Silicium," Doin \& Cie, Paris, 1973.

[36] G. Millot, "Silice, Silex, Silicifications et Croissance des Cristaux," Bull. Serv. Carte géol. Als. Lorr., Vol. 13, 1960, pp. 167-176.

[37] G. Millot and R. Fauck, "Sur L'Origine de la Silice des Silicifications Climatiques et des Diatomites Quaternaires du Sahara," Comptes Rendus de l'Académie des Science, Paris, Vol. 272, 1971, pp. 4-7.

[38] N. Winspear and K. Pye, "The Origin and Signifiance of Boxwork Clay Coatings on Dune Sand Grains from the Nebraska Sand Hill, USA," Sedimentary Geology, Vol. 94, 1995, pp. 245-254. doi:10.1016/0037-0738(94)00090-H

[39] W. Krumbein and K. Jens, "Biogenic Rock Varnishes of the Negev Desert (Israël) an Ecological Study of Iron and Manganese Transformation by Cyanobacteria and Fungi," Oecologia, Vol. 50, 1981, pp. 25-38. doi:10.1007/BF00378791

[40] J. Adams, F. Palmer and J. Staley, "Rock Weathering in Desert: Mobilisation and Concentration of Ferric Iron by Microorganisms," Geomicrobiology Journal, Vol. 10, 1992, pp. 99-114. doi:10.1080/01490459209377910

[41] M. Sarnthein, G. Tetzlaff, B. Koopmann, K. Wolter and U. Pflaumann, "Glacial and Interglacial Wind Regimes over the Eastern Subtropical Atlantic and North-West Africa," Nature, Vol. 293, 1981, pp. 193-196. doi:10.1038/293193a0

[42] S. Caquineau, A. Gaudichet, L., Gomes, M. C. Magouthier and B. Chatenet, "Saharian Dust: Clay Ratio as Relevant Tracer to Assess the Origin of Soil Derived Aerosols," Geophysical Research Letters, Vol. 25, No. 7, 1998, pp. 983-986. doi:10.1029/98GL00569

[43] A. S. Goudie and N. J. Middleton, "Saharian Dust Storms: Nature and Consequences," Earth-Science Review, Vol. 56, No. 1-4, 2001, pp. 179-204. doi:10.1016/S0012-8252(01)00067-8

[44] G. H. Mac Tainsh and P. H. Walker, "Nature and Distribution of Harmattan Dust," Zeitschrift fuer Geomorphologie, Vol. 26, No. 4, 1982, pp. 417-435.

[45] J. P. Carmouze, "La Régulation Hydrogéochimique du lac Tchad. Contribution à L'Analyse Biogéodynamique d'un Système Lacustre Endoréique en Milieu Continental Cristallin," Thesis-Lamsade-Université Paris, doc. ORSTOM 58, 1976.
[46] Z. Garba, "Dynamique des Transports Éoliens et Enregistrement Sédimentaire de L'Aridité à la Limite Sahara-Sahel Depuis 15,000 Ans (Massif de Termit et Manga méridional, Niger)," Ph.D. Thesis, Département des Sciences de la Terre, Université de Bourgogne, Dijon, France, 1997.

[47] P. Felix-Henningsen, "Paleosols on Pleistocene Dunes as Indicators of Paleo-Monsoon Events in the Sahara of East Niger," Catena, Vol. 41, No. 1-3, 2000, pp. 43-60. doi:10.1016/S0341-8162(00)00108-9

[48] J.-P. Carmouze and G. Pedro, "Influence du climat sur le Type de Régulation Saline du lac Tchad. Relations avec les Modes de Sédimentation Lacustre," Science Geology Bulletin, Vol. 39, 1977, pp. 33-49.

[49] J.-Y. Gac, "Géochimie du Bassin du lac Tchad. Bilan de L'Altération, de L'érosion et de la Sédimentation. Travaux et," doc. ORSTOM, Vol. 123, 1980.

[50] A. Yaïr, "Runoff Generation in a Sandy Area-The Nizzana Sands, Western Negev, Israël," Earth Surface Processes and Landform, Vol. 15, 1990, pp. 597-609.

[51] E. Verrecchia, A. Yaïr, J. Ribier, G. Kidron and K. Rolko, "Rôle des Cyanobactéries Dans la Fixation des Sols Sableux Désertiques: Approche d'un Cas Dans le Désert du Néguev (Région de Nizzana, Israël)," Palynosciences, Vol. 2, 1993, pp. 255-266.

[52] F. Pirard, "Hydrogéologie du Niger Oriental," BRGM, Dakar, 1962.

[53] J. Ch. Fontes, "Isotopes du Milieu et Cycles des Eaux Naturelles: Quelques Aspects," Doctorat d'état Thesis, University, Paris VI. 1976.

[54] A. Durand and J. Lang, "Approche Critique des Méthodes de Reconstitution Paléoclimatique: Le Sahel nigérotchadien Depuis 40000 ans," Bulletin de la Societe Geologique de France, Vol. 2, 1986, pp. 267-278.

[55] J. Fabre and N. Petit-Maire, "Holocene Climatic Evolution at $22-24^{\circ} \mathrm{N}$ from Two Paleolakes in the Taoudenni Area (Northern Mali)," Palaeogeography, Palaeoclimatology, Palaeoecology, Vol. 65, 1988, pp. 133-148. doi:10.1016/0031-0182(88)90020-X

[56] A. Durand, F. Paris and J.-F. Saliège, "Peuplements et Environnements Holocènes du Bassin Oriental de L'AZAWAGH," In : F. Paris, E. Bernus and P. Cressier, Eds., Vallée de L'Azawagh (Sahara du Niger), Etudes Nigériennes 57, Sépia, Saint-Maur, 1999, pp. 7-183.

[57] G. H. Mac Tainsh, "The Nature and Origin of the Aeolian Mantles of Central Northern Nigeria," Geoderma, Vol. 33, 1984, pp. 13-37. doi:10.1016/0016-7061(84)90087-9

[58] B. J. Smith and W. B. Whalley, "Late Quaternary Drift Deposits of North Central Nigeria examined by Scanning Electron Microscopy," Catena, Vol. 8, 1981, pp. 345367. 